\title{
Soil archives of a Fluvisol: subsurface analysis and soil history of the medieval city centre of Vlaardingen, the Netherlands - an integral approach
}

\author{
Sjoerd Kluiving ${ }^{1,5}$, Tim de Ridder ${ }^{2}$, Marcel van Dasselaar ${ }^{3}$, Stan Roozen ${ }^{4}$, and Maarten Prins ${ }^{4}$ \\ ${ }^{1}$ Dept. of Archaeology, Faculty of Humanities, Vrije Universiteit Amsterdam, De Boelelaan 1079, \\ 1081 HV Amsterdam, the Netherlands \\ ${ }^{2}$ VLAK (Archaeology Dept), City of Vlaardingen, Hoflaan 43, 3134 AC Vlaardingen, the Netherlands \\ ${ }^{3}$ Arnicon, Archeomedia 2908 LJ Capelle aan den IJssel, the Netherlands \\ ${ }^{4}$ Department of Earth Sciences, Faculty of Earth and Life Sciences, Vrije Universiteit Amsterdam, \\ De Boelelaan 1085, 1081 HV Amsterdam, the Netherlands \\ ${ }^{5}$ CLUE+ Research Institute for Culture, History and Heritage, Vrije Universiteit Amsterdam, \\ De Boelelaan 1079, 1081 HV Amsterdam, the Netherlands
}

Correspondence to: Sjoerd Kluiving (s.j.kluiving@ vu.nl)

Received: 13 November 2015 - Published in SOIL Discuss.: 15 January 2016

Revised: 6 May 2016 - Accepted: 11 May 2016 - Published: 20 June 2016

\begin{abstract}
The medieval city of Vlaardingen (the Netherlands) was strategically located on the confluence of three rivers, the Maas, the Merwede, and the Vlaarding. A church of the early 8th century AD was already located here. In a short period of time, Vlaardingen developed in the 11th century AD into an international trading place and into one of the most important places in the former county of Holland. Starting from the 11th century AD, the river Maas repeatedly threatened to flood the settlement. The flood dynamics were registered in Fluvisol archives and were recognised in a multidisciplinary sedimentary analysis of these archives.

To secure the future of these vulnerable soil archives an extensive interdisciplinary research effort (76 mechanical drill holes, grain size analysis (GSA), thermo-gravimetric analysis (TGA), archaeological remains, soil analysis, dating methods, micromorphology, and microfauna) started in 2011 to gain knowledge on the sedimentological and pedological subsurface of the settlement mound as well as on the well-preserved nature of the archaeological evidence. Pedogenic features are recorded with soil description, micromorphological, and geochemical (XRF - X-ray fluorescence) analysis. The soil sequence of $5 \mathrm{~m}$ thickness exhibits a complex mix of "natural" as well as "anthropogenic" layering and initial soil formation that enables us to make a distinction between relatively stable periods and periods with active sedimentation. In this paper the results of this interdisciplinary project are demonstrated in a number of cross-sections with interrelated geological, pedological, and archaeological stratification. A distinction between natural and anthropogenic layering is made on the basis of the occurrence of the chemical elements phosphor and potassium.

A series of four stratigraphic and sedimentary units record the period before and after the flooding disaster. Given the many archaeological remnants and features present in the lower units, in geological terms it is assumed that the medieval landscape was submerged while it was inhabited in the 12th century AD. In reaction to a final submersion phase in the late 12 th century $\mathrm{AD}$, the inhabitants started to raise the surface of the settlement. Within archaeological terms the boundary between natural and anthropogenic layers is stratigraphically lower, so that in the interpretation of archaeologists, the living ground was dry during the 12th and the 13th centuries AD. In this discussion, the geological interpretation will be compared with alternative archaeological scenarios.
\end{abstract}




\section{Introduction}

Since the fifties of the last century, archaeological excavations in the city centre of Vlaardingen started to change the view on Vlaardingen's history first adopted by 17th- and 18th-century historians that the old medieval city was flooded by the river Maas (Fig. 1; De Ridder, 2002). Archaeological finds in the research area are dated to the Middle Ages (AD 500-1500), while archaeological excavations in the city centre south of the old church revealed the border of a medieval cemetery that was in use between AD 1000 and 1050 . This discovery led to a more complete story of the medieval structure of Vlaardingen and made clear that today's position of the church was also the position in AD 1000. Assuming that there were no other reasons to move the church, it must have been the same position in AD 726/727 (Koch, 1970, number 2).

Despite a long period of archaeological research combined with soil observations, a number of research questions regarding the landscape and soil development still exist. Based on previous research a number of fluvial channels are assumed to date from the Iron Age, Roman period, and Middle Ages spanning a period of almost 2000 years of dynamic landscape and soil development (De Ridder and van Loon, 2007; Kluiving and Vorenhout, 2010, 2011). It is still unknown what the exact location, age of initiation, and cessation of river gullies was. Also, the extent, nature, and stratification of the thick anthropogenic cover layer that underlies the old town has not been systematically researched in the past. In general, the complex interrelation between natural processes like river flow, sea level rise, and flooding and the cultural history of Vlaardingen and initial soil development will be addressed in this paper.

Archaeological research in general is dedicated to smallscale excavations or limited coring campaigns that do not always address such complex interactions of dynamic landscape development and cultural habitation. This problem is further exacerbated by the built-up nature and protected status of the old city of Vlaardingen because the narrow streets and old infrastructure do not allow large-scale excavations or intensive coring campaigns to take place. In addition, currently, developments rarely take place that make archaeological research necessary according to Dutch legislation.

This site evolution is based on a multi-proxy approach based on the soil archives using a combination of multiple research methodologies and correlations of heterogeneous results that is paramount in geoarchaeological research. Standard descriptions of mechanical drill holes, grain size analysis (GSA), thermo-gravimetric analysis (TGA), dating of archaeological remains, soil analysis, carbon-14 dating methods, micromorphology, and microfauna are combined in this paper. The approach is taken in this paper in order to reconstruct the fluvial history and deposition of the past 3000 years of this region together with the formation of Fluvisols and the archaeological and settlement history. Fluvisols are char-

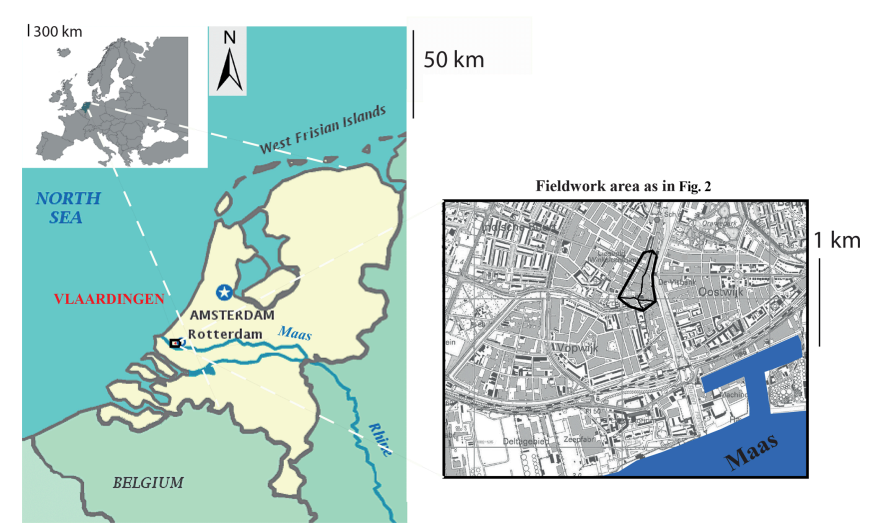

Figure 1. Map of Europe and the Netherlands showing locations of main cities and Vlaardingen, location of study area.

acterised as having parent material originating from fluvial and estuarine sedimentation, and they can be sandy, silty, or clayey. The next step in soil evolution of Fluvisols can be (1) the transformation of sedimentary lamination into a more homogenous horizon due to bioturbation, (2) decalcification, (3) an increase in soil organic carbon, and (4) the translocation of clay particles from the actual Be to a (future) Bt horizon. Such processes can identify initial soil development during a period of landscape stability. In a next phase in pedological terms, clay translocation causes the formation of Luvisols. The good natural fertility of most Fluvisols and the attraction of dwelling sites on river levees and on higher parts in marine landscapes were recognised in prehistoric times (FAO, 2007; WRB, 2014).

An important advantage of this study is the collaboration between geologists and archaeologists to approach the intertwined relation between natural processes and cultural activities in an urban context. Combining different aspects of scale as well as measurement methods with historical data (cf. van de Biggelaar et al., 2014) has not been a straightforward task so far. The results of this study, and especially the sequence of events around the historical flooding of 21 December AD 1163 (Buisman and Van Engelen, 2000, p. 348-349; and Hoek, 1973), will be further elaborated in the discussion. In an archaeological context the boundary between natural and anthropogenic layers is interpreted to be at a lower elevation than it is based on geological arguments. This has major implications on how the medieval history of Vlaardingen has to be understood. From an archaeological point of view the terp was a safe and dry living environment, while a geological interpretation indicates that the church hill was regularly flooded in the 12th and 13th century, during which relatively thick sediment layers were deposited. This elementary conflict in interpretation may have an impact on other research that focusses on distinguishing between natural and anthropogenic layers. This could have major implications for research on other dikes and terps in the Holocene plains of NW Europe. In this paper a geological analysis and inter- 
pretation will be carried out, the outcome of which will be compared in the discussion with alternate archaeological interpretations.

\section{Background}

The location of Vlaardingen in the early Holocene, around 7500 years BP, was in a tidal basin that was influenced by river drainage. Around 6300 years BP, the location changed into a wetland environment with swamps and small lakes (Hijma et al., 2009). Between 6300 and 5000 years BP, the area was transformed into a peat-growing environment, locally first alternating with silty clay of estuarine deposits (Echteld Formation), then alternating with shallow marine deposits of the Wormer Layer of the Naaldwijk Formation (clay with very fine sand layers - salt marshes). Due to these dynamic processes, the Holland Peat layer is not continuous, unlike classical Dutch Holocene stratigraphy, so that in some locations the late Holocene Walcheren layer of the Naaldwijk Formation, deposited in the last 2500 years, is directly on top of the Wormer layer, while in other locations the Holland Peat layer is in between these two marine layers of the Naaldwijk Formation (Hijma et al., 2009). Many cultural traces of the Iron Age and Roman period (2750-2000 years BP) have been retrieved in this landscape around Vlaardingen, such as west of Vlaardingen (Vos and Eijskoot, 2009). Generally, the Wormer layer can be found below $3 \mathrm{~m}$-NAP, while the Walcheren layer is located above $3 \mathrm{~m}-\mathrm{NAP}$. In the late Middle Ages the actual surface was at $1 \mathrm{~m}+\mathrm{NAP}$, right before significant surface lowering due to peat exploitation. Currently, that surface is lowered locally to $2 \mathrm{~m}-\mathrm{NAP}$ (Vos and Eijskoot, 2009), although the surface may be higher above old gully complexes that have become inversion ridges.

Around 1300 years BP (AD 700) a church was founded on the point bar ridge of the Vlaarding creek; the church was given by Heribald to the well-known missionary Willibrord. North of it, and at a later stage also around the church, a settlement developed that has been called Vlaardingen (van Loon and de Ridder, 2007). Vlaardingen is one of the oldest settlement nuclei of the western Netherlands, and in the 11 th and 12 th centuries AD, it developed into one of the most important settlements in the county of Holland. From the count's court, the systematic peat exploitation around the settlement was coordinated. In the second half of the 11th century $\mathrm{AD}$, in this county's capital, coins were produced for the first time on which the title of count appears. In the year AD 1163 Vlaardingen was struck by a severe flooding disaster, which had serious consequences for the settlement. Large pieces of domesticated landscapes (cf. Widgren, 2012) were lost and had to be reclaimed. Vlaardingen received city rights early 13 th century, and these were confirmed in writing in AD 1273. On the other hand, the importance of the city decreased relative to other cities in Holland in the 13th and 14th centuries AD. The settlement grew around the church and terp, but the expansion was limited due to the dikes, a situation that continued until the Industrial Revolution in the 19th century AD (Torremans and de Ridder, 2007).

The actual centre of the city is located on a medieval terp around the old church. This eventually resulted in a mound with a surface area of 200 by $250 \mathrm{~m}$, built up in a 4-5 m thick sequence of clay and manure in which organic remains of former occupation are extremely well preserved, e.g. wooden posts, mesh walls but also leather objects. Recently, graves were found in the city centre, dating to AD 1000-1050, in which not only the wooden coffins but the straw that covered the deceased was also present. In human teeth, DNA appeared to be well preserved and is classified as the oldest in the country, thus turning the church hill into a large database of human DNA (De Ridder et al., 2008). Vlaardingen was a principal settlement in the past. In this paper we attempt to link the rise and fall of a city like Vlaardingen with the fluvial and tidal dynamics in this region and to show how important the analysis of soil archives of Fluvisols can be in reconstructing landscape development.

\section{Material and methods}

In order to address complex research questions around the history of the city of Vlaardingen in relation to the changing landscapes and soil profiles in this once flooded area, as well as to overcome logistical problems of access to the old city, a systematic mechanical coring campaign (Macro-Core) was carried out $(n=76)$, with a core diameter of $5 \mathrm{~cm}$. The location of cores was planned so as to create specific profiles and took place in the streets and in other places that were accessible (Fig. 2). Special permission was granted by the city council to raise the paving in order to employ the coring device. Core depth ranged between 6 and $9 \mathrm{~m}$ below street level (Table 1).

All cores were transported to the laboratory, where they were cut for standard sediment description (Bosch, 2008), sampling, and further laboratory analysis.

Mechanical coring delivered samples of the subsurface on a metre scale. Mechanical coring caused hiatuses in coring sequence; in profile sequences, these hiatuses are depicted, and in layer and unit correlations the deposit above the hiatus is assumed to be maximised to the metre scale.

A total of 211 sediment samples were used for grain size analysis and the determination of organic and calcareous content. Sediment analysis was performed at the Sediment Analysis Laboratory of the VU University Amsterdam. Grain size analysis with a Sympatec HELOS KR laser-diffraction particle sizer was applied in order to quantify grain size distributions and make statistical comparisons and analyses. The latter was archived through endmember analysis (cf. Weltje and Prins, 2003), which aims at unmixing the varying grain size distributions and identifying a limited number of endmembers that best represent the data set. The results can 


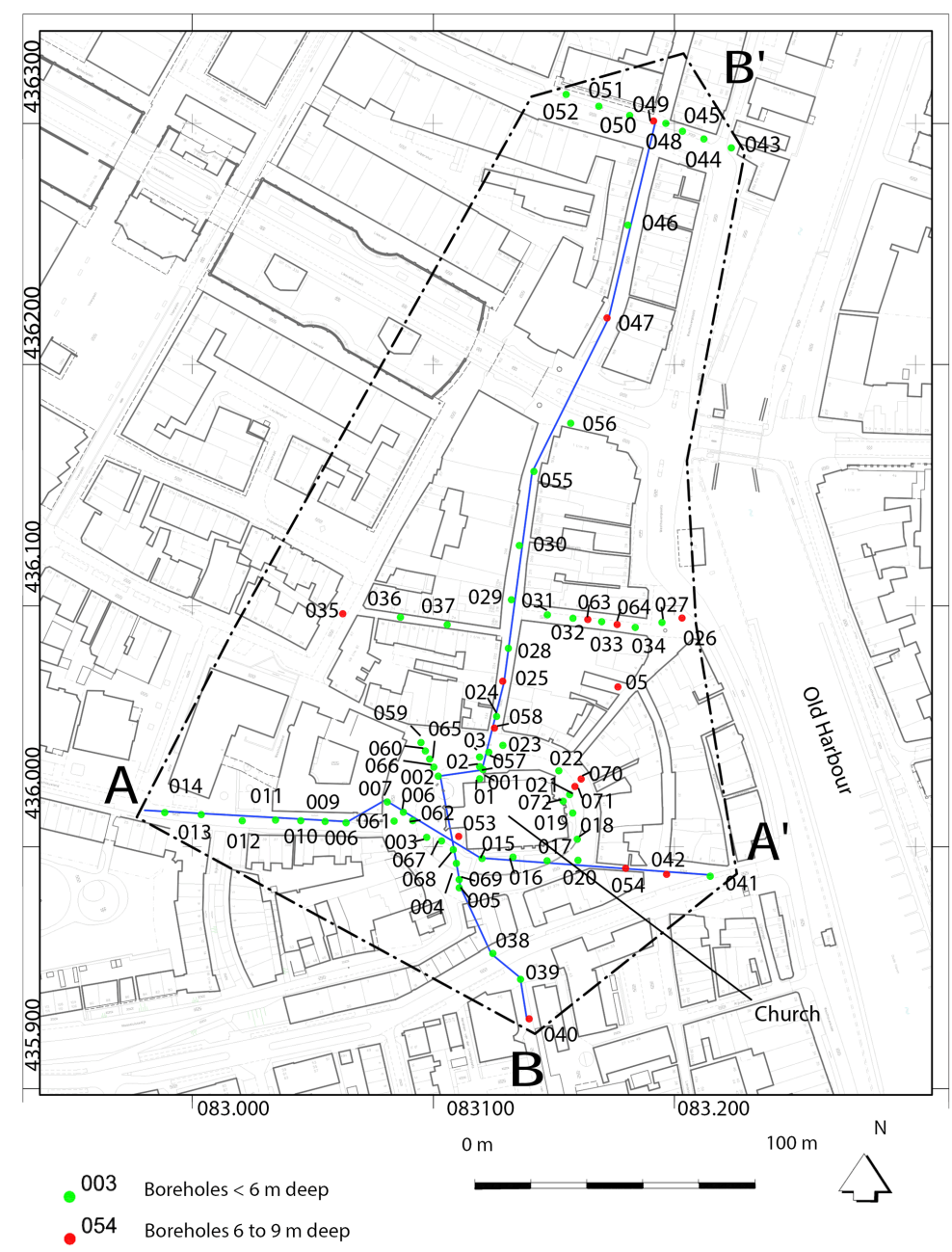

Figure 2. Study area within city centre of Vlaardingen (Stadshart) with locations of 76 mechanical cores and the position of two crosssections $\mathrm{A}$ and $\mathrm{B}$.

Table 1. Metrical data of cores in Vlaardingen Stadshart (city centre).

\begin{tabular}{ll}
\hline $\begin{array}{l}\text { Number of mechanical cores, } \\
\text { core diameter } 5 \mathrm{~cm}\end{array}$ & $\begin{array}{l}\text { Depth of core below } \\
\text { street level, } \\
\text { in metres }\end{array}$ \\
\hline 60 & 6 \\
1 & 7 \\
15 & 9 \\
Total: 76 & - \\
\hline
\end{tabular}

be used to distinguish between lithological units, related to sediment sources or depositional mechanisms. Furthermore, thermo-gravimetric analysis with a Leco TGA 701 was applied to quantify the organic matter and carbonate content of the sediment samples. Results of TGA and GSA analyses as well as extensive description have already been published elsewhere (Kluiving et al., 2014).
Micromorphology was described on 21 thin sections of $15 \times 3 \mathrm{~cm}$ of 13 mechanical cores. Undisturbed samples were air-dried before being impregnated with a colourless unsaturated polyester resin. After the vaporisation of the main part of the acetone, samples were hardened by gamma radiation. Thin sections were prepared from the blocks (cf. Jongerius and Heintzberger, 1975), which were analysed with a polarising microscope and a $200 \times$ magnification (cf. Courty et al., 1989). Results of these analyses as well as an extensive description have already been published (Kluiving et al., 2014).

Small volumes of sediment were sieved through a sieve with $2 \mathrm{~mm}$ mesh from multiple intervals from 28 cores $(n=$ $67)$. Based on combinations of species as well as conservation status, it is assumed that freshwater and land animals had their habitat in local regional areas, while the saltwater specimens have their provenance in the North Sea and Wadden Sea. Shells and shell remains were analysed using expert knowledge, as reported in Kluiving et al. (2014). 


\begin{tabular}{|c|c|c|c|c|}
\hline \begin{tabular}{|l|} 
VLAA- \\
sample no.
\end{tabular} & $\begin{array}{l}\text { Poz-lab. } \\
\text { no. }\end{array}$ & $\begin{array}{l}\text { C-14 years } \\
\text { BP }\end{array}$ & $\begin{array}{l}\text { Core no. (core } \\
\text { depth } \mathrm{cm} \text { ) }\end{array}$ & $\begin{array}{l}\text { Material } \\
\text { dated }\end{array}$ \\
\hline 1 & 45584 & $1425 \pm 30$ & 17 (500-515) & W \\
\hline 2 & 45585 & $895 \pm 35$ & $18(433)$ & W \\
\hline 3 & 45586 & $945 \pm 30$ & $53(500-520)$ & W \\
\hline 4 & 45587 & $940 \pm 30$ & $53(463-478)$ & W \\
\hline 5 & 45589 & $1090 \pm 30$ & $18(366)$ & W \\
\hline 6 & 45590 & $915 \pm 30$ & 25 (500-505) & W \\
\hline 7 & 45591 & $1075 \pm 30$ & 31 (532) & W \\
\hline 8 & 45592 & $850 \pm 30$ & $06(260-300)$ & W \\
\hline 9 & 45593 & $1140 \pm 30$ & $25(480)$ & W \\
\hline 10 & 45594 & $1110 \pm 30$ & $56(532)$ & W \\
\hline 11 & 45595 & $895 \pm 30$ & $33(454)$ & W \\
\hline 12 & 45604 & $1060 \pm 35$ & $37(433-450)$ & W \\
\hline 13 & 45761 & $935 \pm 25$ & 19 (345-372) & W \\
\hline 14 & 45596 & $935 \pm 30$ & 03 (315-357) & W \\
\hline 15 & 45597 & $1025 \pm 30$ & $20(580)$ & W \\
\hline 16 & 45599 & $1240 \pm 30$ & 20 (436-438) & W \\
\hline 17 & 45600 & $1130 \pm 35$ & $29(438)$ & W \\
\hline 18 & 45644 & $975 \pm 30$ & $54(610)$ & W \\
\hline 19 & 45601 & $990 \pm 30$ & $54(430-440)$ & W \\
\hline 20 & 45602 & $980 \pm 30$ & $54(370)$ & W \\
\hline 21 & 45603 & $1000 \pm 30$ & $54(450-500)$ & W \\
\hline 22 & 46026 & $1045 \pm 30$ & $19(420)$ & B \\
\hline 23 & 46028 & $1085 \pm 25$ & 15 (425-430) & $B$ \\
\hline
\end{tabular}

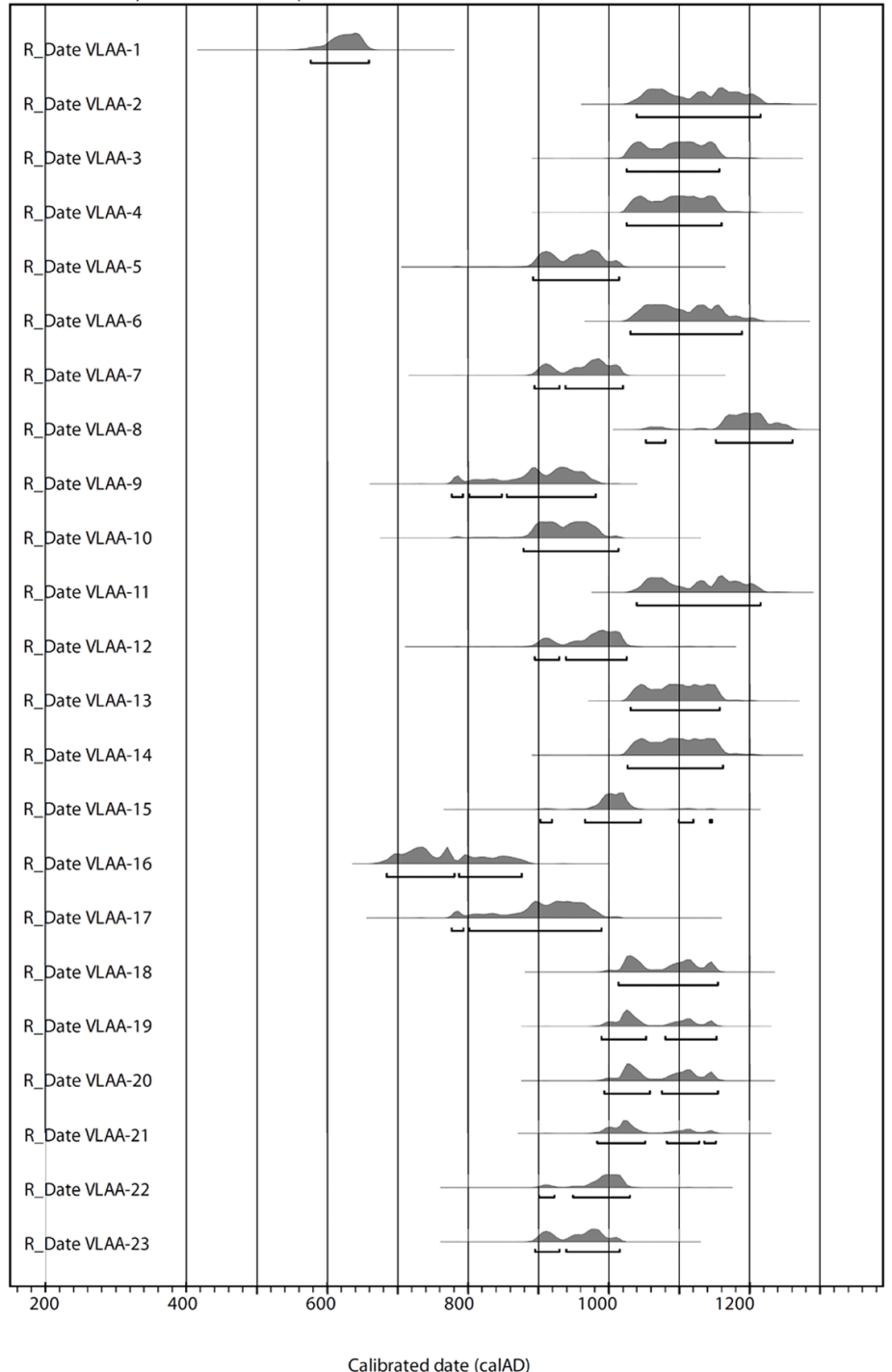

Figure 3. AMS radiocarbon dates; material dated: $\mathrm{W}$ - wood, B - bone.

XRF values were sampled on 10 cores through measurements with a handheld Thermo Scientific Field Mate Niton XRF analyser.

Radiocarbon accelerator mass spectrometry (AMS) dating was carried out in Poznańskim Laboratorium Radiowęglowym in Pozan, Poland, for 23 dates, where 21 samples are dated by bulk organic material and wood and 2 samples are dated by human bone material (Fig. 3).

\section{Results}

\subsection{Lithofacies, sediment composition, and soil characteristics}

Eight main lithofacies units can be distinguished within the studied cores based on macroscopic core description (colour, sedimentary structures, texture; Table 2).
The results of grain size analyses underwent endmember analysis, through which four endmembers could be distinguished (Fig. 4, Table 3). All endmembers have an unimodal grain size distribution. Endmembers can be related to governing factors such as sediment source or depositional mechanism. However, it is difficult to identify anthropogenic actions as a depositional mechanism, although the provenance of specific endmembers may be extrapolated from these units. The combined \% of EM1 and EM2 appears to be high $(>50 \%)$ in units 4, 7-2, 7-3, and 7-1, corresponding to the interpretation of gully deposits from the lithology where energy levels are apparently sustainably high to carry such bedload (Table 3 ).

Unit 4 consists of a rather coarse clayey sand with an EM1 + EM2 being more than $50 \%$. The unit occurs in the higher part of the terp in elongated lenses that reflect a cultur- 
Table 2. All units described in this research above the Holland Peat layer belong to the Walcheren layer of the Naaldwijk Formation and the anthropogenous top layers.

\begin{tabular}{llll}
\hline Unit & Lithology & Natural/cultural & Interpretation \\
\hline 4 & Sand, clayey & Natural or cultural & Gully deposits or culturally deposited \\
5 & Cultural layer (peat) & Cultural & Culturally deposited \\
6 & Cultural layer (other) & Cultural & Culturally deposited \\
$7-1$ & Clay, sandy/sand, silt poor & Natural & Gully deposits \\
$7-2$ & & Natural or cultural & Gully deposits or culturally deposited \\
$7-3$ & & Natural or cultural & Gully deposits or culturally deposited \\
8 & Clay, with sand lamination & Natural & Point bar deposits \\
$9-1$ & Clay, silt poor & Natural & Flood basin deposits (medium-deep water) \\
$9-2$ & Clay, silt poor & Natural or cultural & Flood basin deposits (medium-deep water) or culturally deposited \\
$10-1$ & Clay, silt poor, organic & Natural & Flood basin deposits (shallow water) \\
$10-2$ & Clay, silt poor, organic & Natural or cultural & Flood basin deposits (shallow water) or culturally deposited \\
$11-1$ & Peat, & Natural & Holland Peat, Nieuwkoop Formation \\
$11-2$ & Peat, & Natural & Holland Peat, Redeposited \\
12 & Clay, silt poor & Natural & Wormer layer, Naaldwijk Formation \\
\hline
\end{tabular}

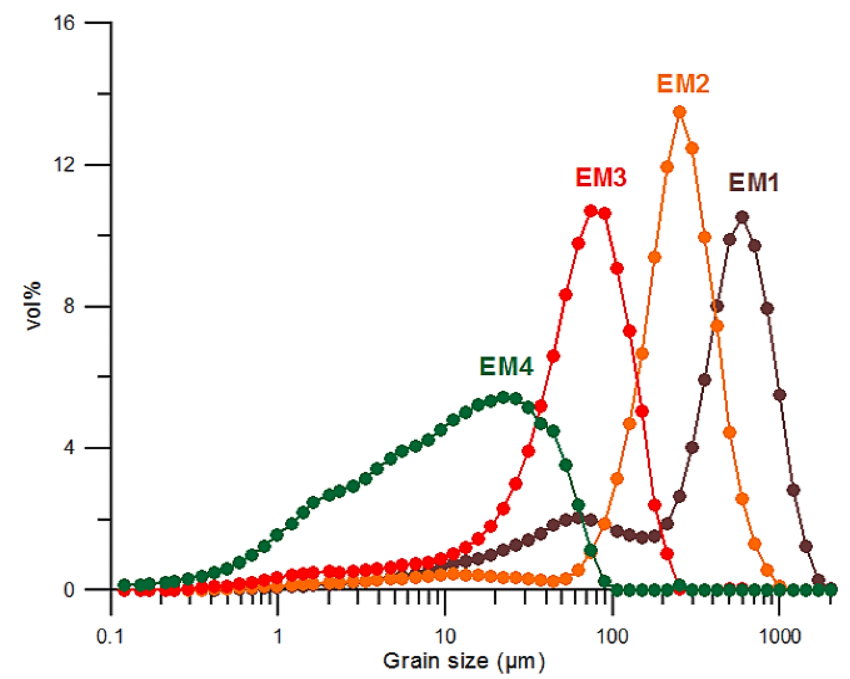

Figure 4. Modelled grain size and division of endmembers in Vlaardingen Stadshart.

ally induced depositional mechanism (system 6). However, a few isolated lenses of unit 4 also occur; based on this association, this unit can have a natural as well as a cultural origin.

Unit 5 is a layer with a large component of peat, described as dark (black) with natural stones and shell remains, sandy and loose in packing. Various organic remains like wood and plant remains occur. Usually this unit is intermixed with unit 6 . The unit is also sandy in nature, as is shown by an $\mathrm{EM} 1+\mathrm{EM} 2$ percentage of $33 \%$, and is interpreted as a cultural layer, meant to artificially raise the surface (cf. van Dasselaar, 2011).

Unit 6 consists of black silty and sandy clay layers with a large humic content, mixed with bones and other archae-
Table 3. Endmember data organised in units and subunits, specified by systems.

\begin{tabular}{|c|c|c|c|c|c|c|c|}
\hline \multirow[t]{2}{*}{ Unit } & \multirow[t]{2}{*}{ System } & EM1 & EM2 & EM3 & EM4 & $n$ & \multirow{2}{*}{$\begin{array}{r}\text { Sum EM1 } \\
\text { and EM2 } \\
(\%)\end{array}$} \\
\hline & & \multicolumn{4}{|c|}{$(\%)$} & & \\
\hline \multirow[t]{2}{*}{4} & 3.1 & 12.34 & 19.32 & 58.95 & 9.40 & 2 & 31.65 \\
\hline & 6 & 6.62 & 56.48 & 3.95 & 32.95 & 3 & 63.10 \\
\hline \multirow[t]{2}{*}{5} & 3.1 & 0.95 & 9.34 & 25.83 & 63.88 & 2 & 10.30 \\
\hline & 6 & 8.99 & 36.00 & 33.20 & 21.81 & 4 & 44.99 \\
\hline \multirow[t]{3}{*}{$7-1$} & 1 & 0.00 & 7.75 & 85.33 & 6.92 & 2 & 7.75 \\
\hline & 4 & 27.01 & 32.40 & 30.99 & 9.59 & 4 & 59.42 \\
\hline & 5 & 15.86 & 16.92 & 41.84 & 25.38 & 6 & 32.78 \\
\hline \multirow[t]{2}{*}{$7-2$} & 3.1 & 1.69 & 17.95 & 72.60 & 7.76 & 2 & 19.64 \\
\hline & 6 & 16.08 & 44.48 & 17.14 & 22.30 & 13 & 60.56 \\
\hline \multirow{2}{*}{$7-3$} & 3.1 & 1.60 & 0.00 & 63.71 & 34.69 & 1 & 1.60 \\
\hline & 6 & 5.70 & 85.81 & 5.65 & 2.84 & 2 & 91.51 \\
\hline \multirow[t]{5}{*}{8} & 1 & 0.22 & 6.00 & 70.33 & 23.45 & 9 & 6.22 \\
\hline & 2 & 0.26 & 10.05 & 65.98 & 23.71 & 5 & 10.30 \\
\hline & 3 & 0.00 & 12.92 & 75.31 & 11.77 & 2 & 12.92 \\
\hline & 4 & 0.00 & 19.84 & 77.61 & 2.55 & 4 & 19.84 \\
\hline & 5 & 0.24 & 9.36 & 62.11 & 28.29 & 7 & 9.60 \\
\hline \multirow[t]{5}{*}{$9-1$} & 1 & 5.37 & 6.74 & 42.49 & 45.40 & 7 & 12.11 \\
\hline & 2 & 0.38 & 4.64 & 70.51 & 24.47 & 12 & 5.02 \\
\hline & 3 & 0.69 & 1.54 & 50.50 & 47.26 & 1 & 2.24 \\
\hline & 4 & 0.33 & 4.79 & 70.23 & 24.65 & 2 & 5.12 \\
\hline & 5 & 2.11 & 11.26 & 34.82 & 51.82 & 7 & 13.37 \\
\hline \multirow[t]{2}{*}{$9-2$} & 3.1 & 0.53 & 9.17 & 43.28 & 47.02 & 9 & 9.69 \\
\hline & 6 & 3.26 & 16.2 & 44.29 & 36.23 & 8 & 19.48 \\
\hline \multirow[t]{5}{*}{$10-1$} & 1 & 1.78 & 3.95 & 48.49 & 45.78 & 14 & 5.73 \\
\hline & 2 & 1.37 & 0.00 & 11.42 & 87.22 & 1 & 1.37 \\
\hline & 3 & 2.71 & 9.12 & 50.91 & 37.25 & 9 & 11.83 \\
\hline & 4 & 0.00 & 10.18 & 84.47 & 5.34 & 1 & 10.18 \\
\hline & 5 & 1.32 & 15.19 & 36.31 & 47.18 & 8 & 16.51 \\
\hline $10-2$ & 3.1 & 5.37 & 14.18 & 36.48 & 43.98 & 20 & 5.73 \\
\hline $11-2$ & 6 & 6.19 & 21.17 & 36.65 & 35.99 & 12 & 27.36 \\
\hline
\end{tabular}


ological remains; it occurs in association with unit 5 and is interpreted as a cultural layer (cf. van Dasselaar, 2011).

Unit 7 is a sandy clay to silt-poor sand, in which three subfacies have been recognised. The first subfacies (7-1) has an $\mathrm{EM} 1+2$ proportion of $37 \%$ and a relatively large proportion of EM3 of $45 \%$. The other two subfacies (7-2 and 7-3) have significantly coarser signatures with an EM1 + EM2 percentage 56-61. This facies is associated with gully deposits with a natural origin in the lower subfacies, while the upper two subfacies appear to be culturally influenced because of the coarser nature as well as the presence of artefacts.

Unit 8 is a clay with sand lamination interpreted as point bar deposits with a high proportion of fine endmembers 3 and 4.

Unit 9-1 is a silt-poor clay interpreted as low-energy flood basin deposits dominated by EM3 and 4 of more than $90 \%$ and an EM1 + EM2 percentage of $9 \%$.

Unit 9-2 has a similar lithology but with a slightly higher $\mathrm{EM} 1+\mathrm{EM} 2$ of $12 \%$ and is interpreted as a cultural deposit.

Units 10-1 and 10-2 both consist of organic silt-poor clay interpreted as low-energy flood basin deposits. The two subfacies distinguish a natural facies with EM1 + EM2 being $13 \%$ and a potential more culturally influenced subfacies 10 2 with EM1 + EM2 being $22 \%$. Within the top parts of unit 10-1 at core 29, brown colours and the presence of humus staining are indicative of Fluvisol formation processes. Also, the top of 10-1 in core 39 shows similar characteristics indicative of soil processes.

Unit 11-1 is a natural peat layer, interpreted as the Hollandveen layer of the Nieuwkoop Formation, while the subfacies 11-2 has a relatively higher clastic content, and it occurs in higher stratigraphic contexts; it is therefore interpreted as redeposited peat.

The grain size of the sediments present in the units varies over units but also reveals patterns that confirm the unit subdivision. Large differences exist between the content of coarse components (EM1 $+2 \%$ ) within units 4, 5, 7-2, and $7-3$. In all of these units the sum of EM1 and 2 is very high (45-90\%) for system 6 and significantly lower (2-30\%) for system 3.1 (Table 3 ). The peaty cultural layer of unit 5 differs with a $10 \%$ EM $1+2$ proportion in system 3.1 , while system 6 shows a $45 \%$ proportion. Unit 7-1 varies over systems 1,4 , and 5 , reflecting gully deposits with variable flow energy, showing the lowest energy in system 1 and exhibiting the highest energy in system 4.

\subsubsection{Thin section analysis}

In several cores to the west of the mound in the top of system 1, vegetated point bar deposits with charcoal remains have been interpreted that were regularly burned (Kluiving et al., 2014). Also in the top of system 3 (in core 15), evidence of well-conserved plant remains with artefacts show human presence and there is a carbon-14 date on bone of AD 936-1015 (no. 23; Fig. 3). In core 28 in the top of sys- tem 1 , micro-evidence of cooking remains relating to slag and hearth ash (Kluiving et al., 2014). Artefacts disturbing the top of the peat layer in cores 30 and 55 show the presence of an old surface on top of system 1 that correlates with other cores (Fig. 6a).

\subsubsection{XRF results}

Since XRF values were measured every $40 \mathrm{~cm}$ in core sections (see Sect. 3), results can best be compared with the sedimentary log (Kluiving et al., 2012). Based on this comparison a number of transitions in the occurrence of chemical elements have been established (Table 5).

First, results show that there appears to be a correlation between phosphor $(\mathrm{P})$ and the archaeological sequence. All cores show, in general, a significant drop in $\mathrm{P}$ in the measured samples going downcore. In cores 1, 10, 25, 30, and 35 this relation is especially clear. In cores 1,5 , and 30 it is also observed that in their basal parts these cores show a slight increase in $\mathrm{P}$.

Secondly, it is observed that copper $(\mathrm{Cu})$ and lead $(\mathrm{Pb})$ are also increased in the upper part of the cores, corresponding to the $\mathrm{P}$ trend in the sequence.

Lastly, it appears that the potassium $(\mathrm{K})$ values have more constant levels through all layers (at $0.2 \%$ ), a trend which does not correlate with $\mathrm{P}, \mathrm{Cu}$, or $\mathrm{Pb}$.

Based on the observed trends, boundaries have been drawn that separate naturally deposited layers from archaeological deposits and cultural layers. In most cores more than one transition in $\mathrm{P}, \mathrm{Cu}$, and/or $\mathrm{Pb}$ values is present; only two cores have a single transition from high elevated values in $\mathrm{P}, \mathrm{Cu}$, and/or $\mathrm{Pb}$ from low to zero values (cores 14 and 35; Table 5). At three cores $\mathrm{Cu}, \mathrm{P}$, and/or $\mathrm{Pb}$ values are still slightly elevated below the basal transitions (cores 1, 5, and 30; Table 5). The basal XRF transition depth, from an elevated chemical element value to absence, is in most cases at the top of system 1 or the basal occurrence of system 3 .

\subsubsection{Results of shell analysis}

Shell remains can, after analysis, be split up into three categories: freshwater, saltwater, and continental. Results indicate that we can specify two groups within the analysed shell remains: group A shows exclusively freshwater shells or shell remains, with some continental shell remains $(n=17)$. Group B shows an alternation between saltwater and freshwater remains, alternating with continental remains $(n=12$; Table 6). Within group B saltwater shells and remains often occur higher in the profile above freshwater and continental remains (Figs. 5a, 6a).

\subsubsection{Radiocarbon dating}

Results of the radiocarbon dating program show a two-part division in the spread of radiocarbon dates (Fig. 3). There 
(a)

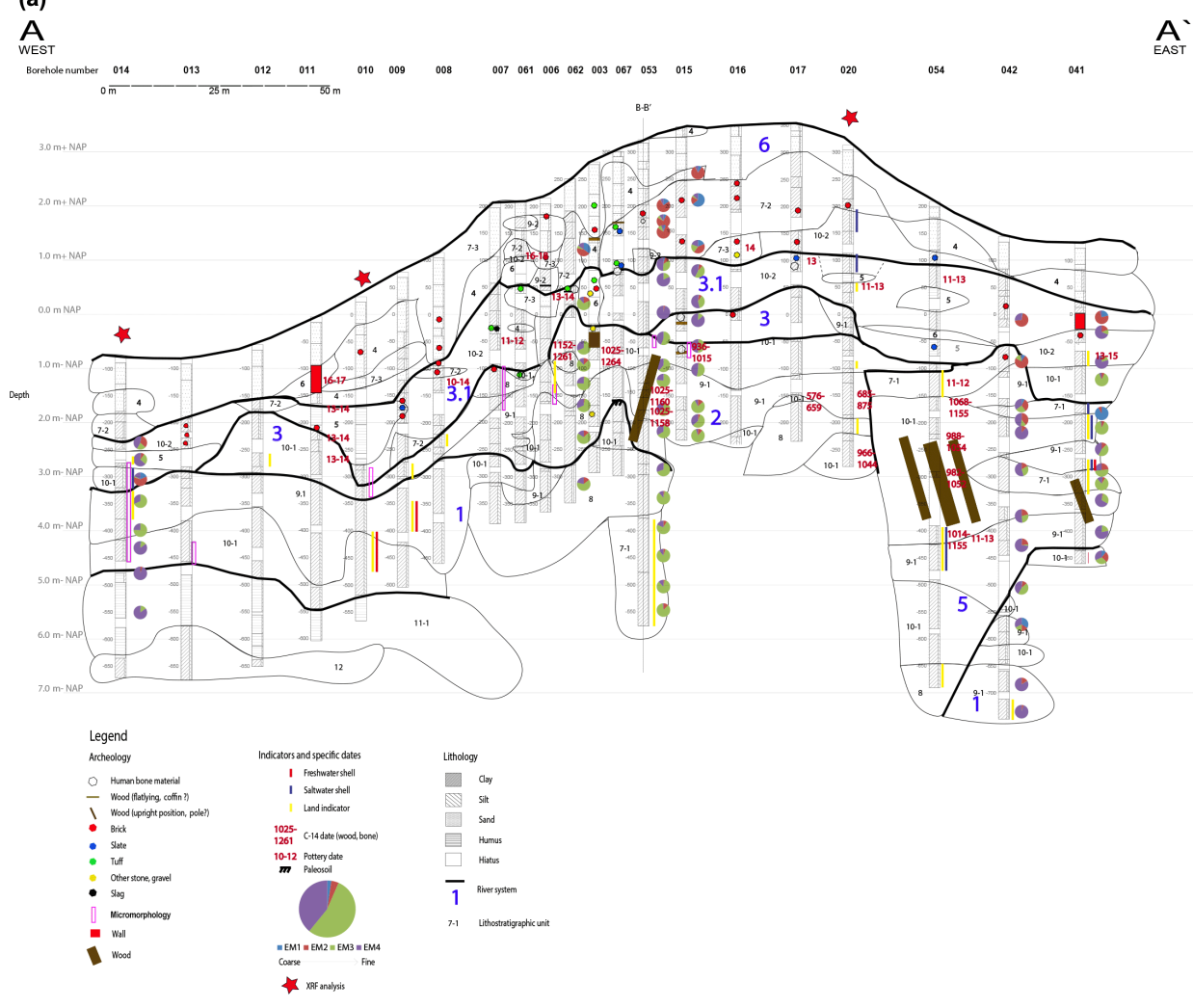

(b)

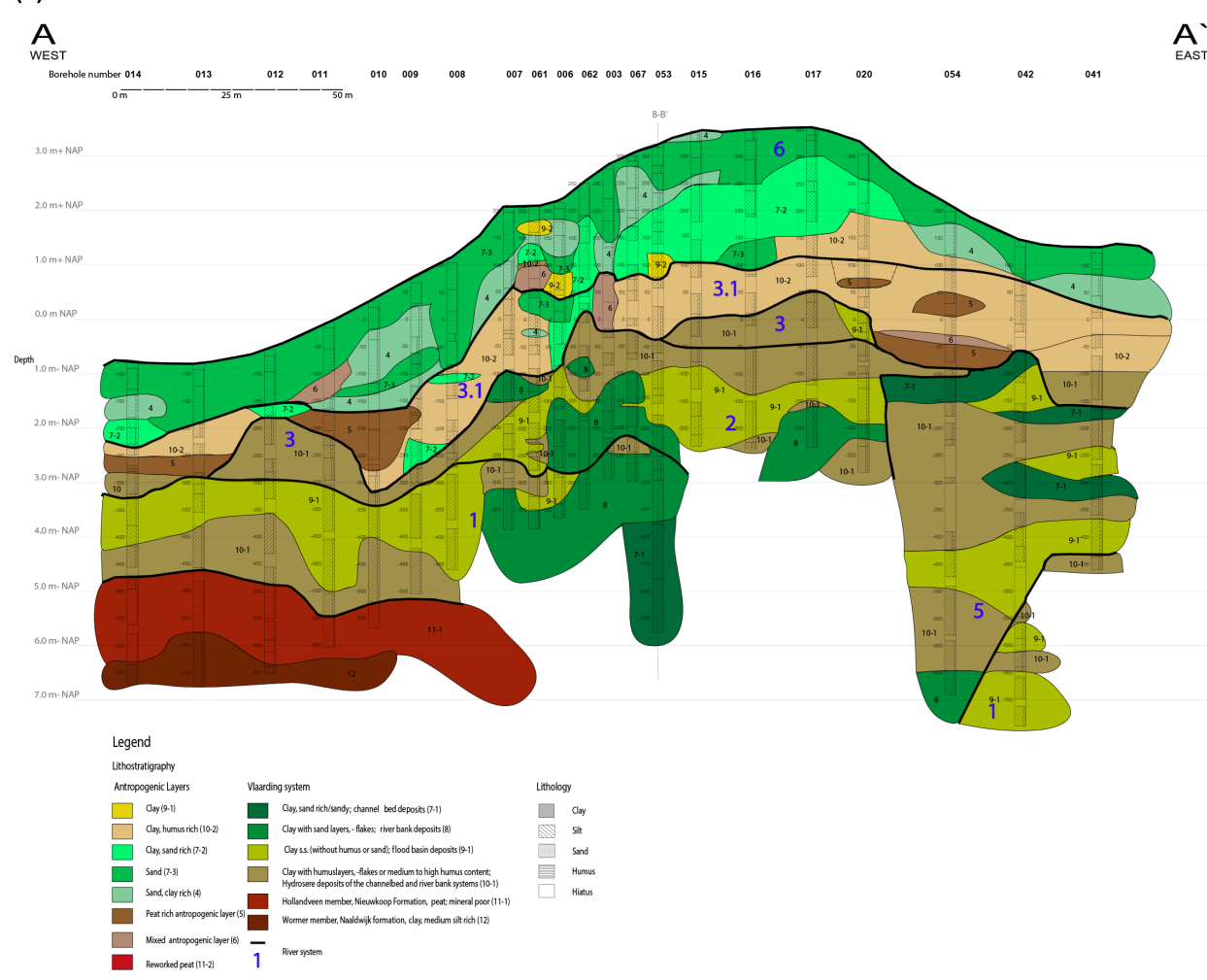

Figure 5. (a) East-west $\left(\mathrm{A}-\mathrm{A}^{\prime}\right)$ cross-section of mound of Vlaardingen Stadshart and its natural subsurface with data sheet. (b) East-west $\left(\mathrm{A}-\mathrm{A}^{\prime}\right)$ cross-section of mound of Vlaardingen Stadshart and its natural subsurface. 
(a)

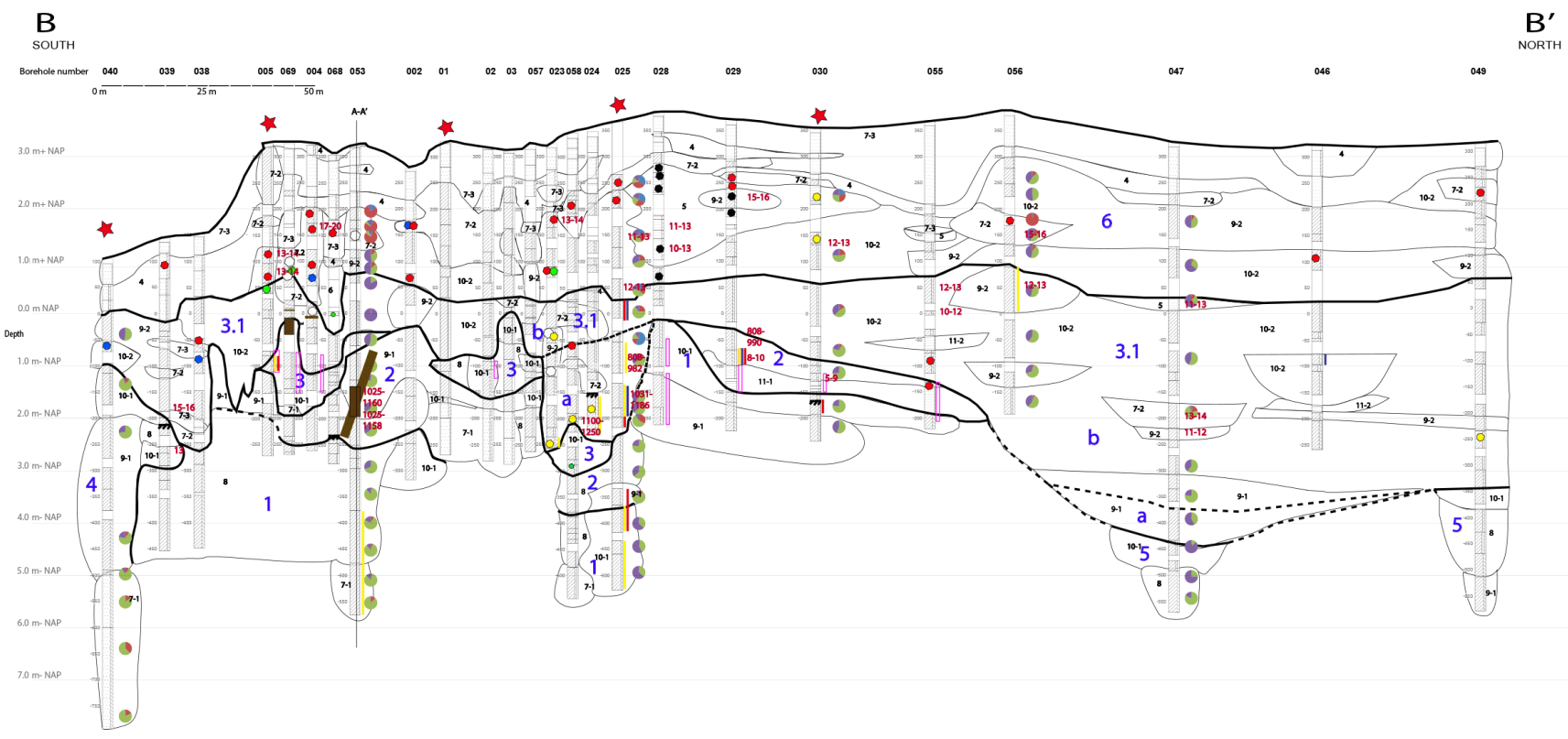

(b)

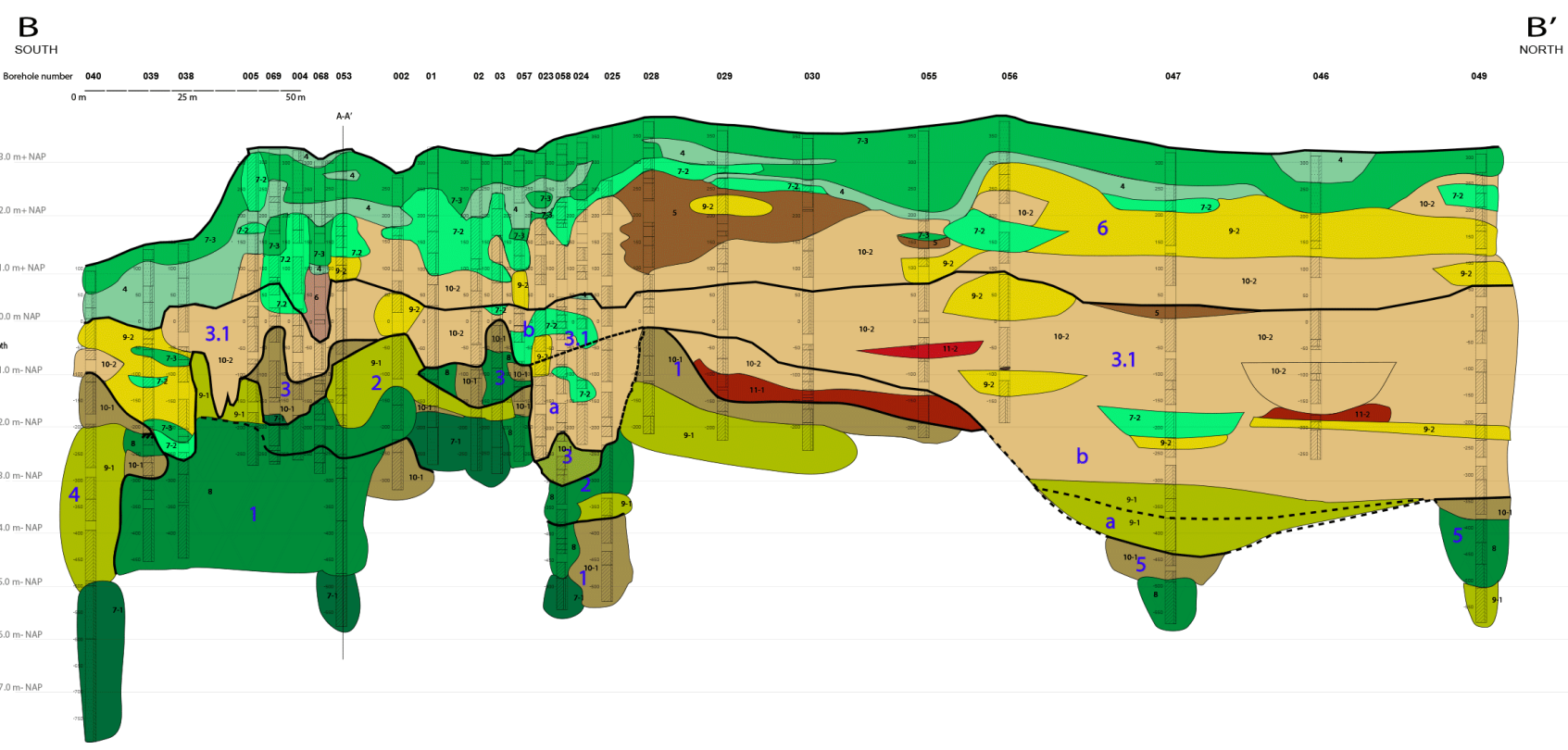

Figure 6. (a) North-south (B-B') cross-section of mound of Vlaardingen Stadshart and its natural subsurface with data sheet. (b) Northsouth $\left(\mathrm{B}-\mathrm{B}^{\prime}\right)$ cross-section of mound of Vlaardingen Stadshart and its natural subsurface.

is a concentration of dates in the period AD 900-1000 and one in the period AD 1050-1200. All radiocarbon dates are plotted in the cross-sections (Figs. 5, 6).

\subsection{Sedimentary and (partly) anthropogenic systems}

Incorporating the results from the field description and laboratory sediment analyses, the lithological facies of the natural deposits and cultural layers were clustered into seven lithogenetic sedimentary and (partly) anthropogenic systems (Table 4).

All systems have a range of lithological units and contain gully, point bar, flood basin, and organic deposits, based on their lithological characteristics (Table 3). Below these units peat and clay deposits are observed that belong, based on their lithology and positional depth, to the Holland Peat layer of the Nieuwkoop Formation (top 4.80-5.50 m -NAP) and 


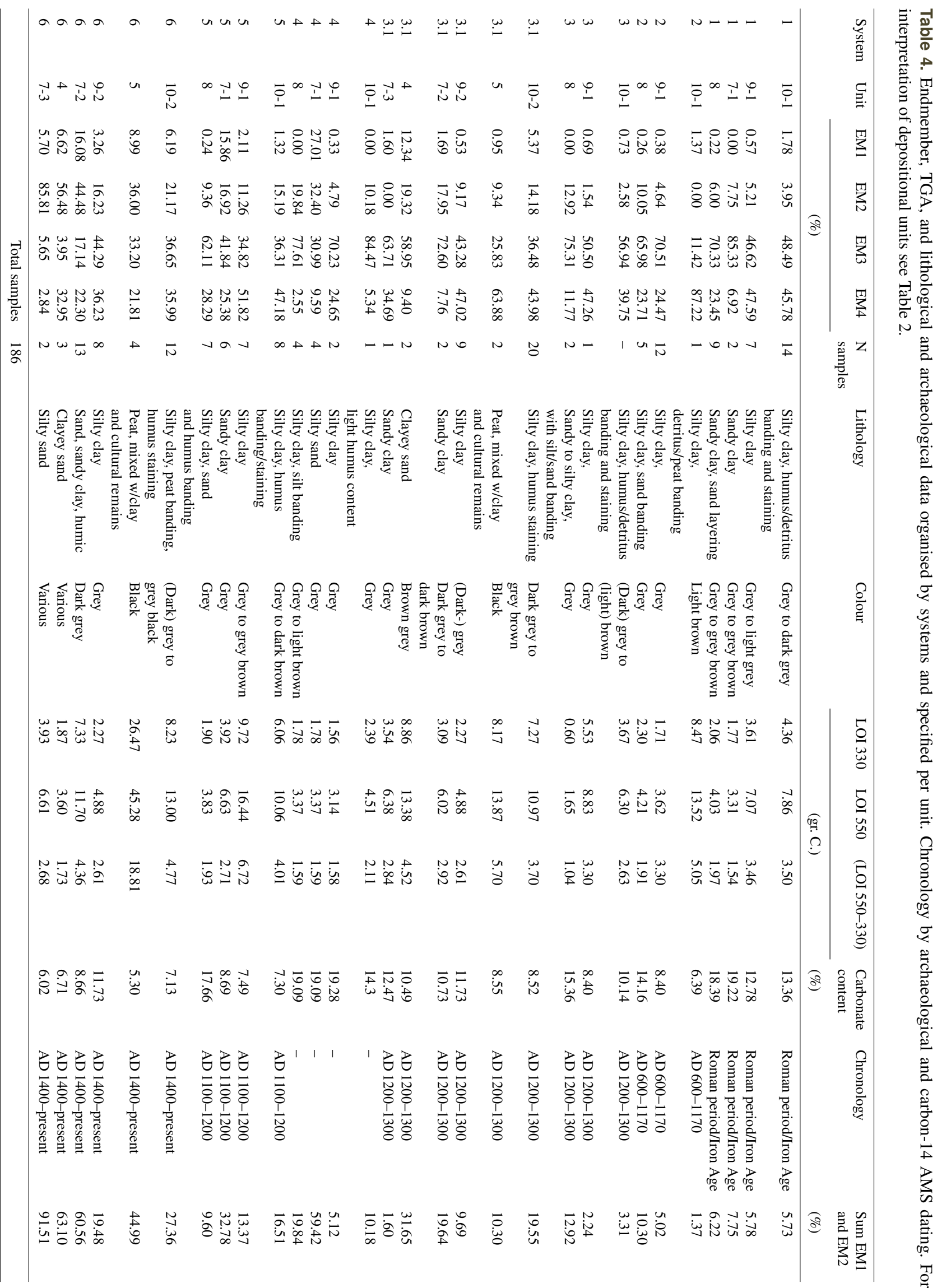


Table 5. Depth of transitions $\mathrm{P}, \mathrm{Cu}$, and/or $\mathrm{Pb}$ as measured by a handheld XRF analyser indicated in metres downcore and relative to NAP. In three cores trends of slightly increasing elements below the basal transition are indicated (*). (“/” indicates multiple changes in sediment layer.)

\begin{tabular}{ll}
\hline Core & Depth of transitions $(/)$ in m downcore $(\mathrm{m}+/-\mathrm{NAP})$ \\
\hline 1 & $-2.55(0.69) /-3.0(0.23) /-4.51(-1.28) / *$ trend $\mathrm{Cu}$ and $\mathrm{P}$ \\
5 & $-2.70(0.58) /-3.20(0.08) /-5.26(-1.98) / *$ trend $\mathrm{Cu}, \mathrm{P}$, and $\mathrm{Pb}$ \\
10 & $-2.37(-2.03) /-3.40(-3.13) /-3.75(-3.42)$ \\
14 & $-2.45(-3.20)$ \\
20 & $-2.55(0.59) /-3.00(0.13) /-3.36(-0.23) /-4.12(-1.00)$ \\
25 & $-2.00(1.66) /-2.40(1.26)-3.40(0.26) /-4.00(-0.34) /-5.00(-1.43)$ \\
30 & $-3.00(0.66) /-4.10(-0.44) /-4.85(-1.29) /-5.21(-1.66) / *$ trend $\mathrm{P}$ \\
35 & $-3.33(-3.22)$ \\
40 & $-2.0(-0.95) /-2.2(-1.15) /-3.04(-1.99) /-5.0(-3.95)$ \\
\hline
\end{tabular}

Table 6. Types of shell remains distributed across cores; ${ }^{*}$ indicates shell remains present in systems 3.1, 5, and 6 .

\begin{tabular}{lll}
\hline Shell remain type & Core numbers & Group \\
\hline Freshwater (and continental) & $1,5,6,8^{*}, 9,10,12,23^{*}, 24^{*}, 26,31^{*}, 35,37,42,50^{*}, 53$, and $56^{*}$ & A $(n=17)$ \\
Saltwater (on top of freshwater) & $14,18,20^{*}, 22^{*}, 25,29^{*}, 30,36,41,45^{*}, 46^{*}$, and $54^{*}$ & B $(n=12)$ \\
\hline
\end{tabular}

the Wormer Layer of the Naaldwijk Formation (top 5.70$6.40 \mathrm{~m}-\mathrm{NAP})$.

All natural and anthropogenic systems contain a range of lithological units (Table 2). These units within the systems are also depicted in the cross-sections in Figs. 5 and 6.

In summary, it is observed that the combined number of EM1 and EM2, the coarsest fraction, shows that coarse and medium sand is more prominent in the higher and younger systems, e.g. systems 3.1 and 6. In system 1 it is striking that the interpreted flood basin clays to be deposited in medium to deep water contain the highest proportion of coarse sediment in relation to the gully and point bar deposits (Table 3). In general, the carbonate contents of the sediments analysed are relatively elevated, with higher values (up till 20\%) in the systems 1 and 4 (Table 4). The lowest values (below 10\%) occur in system 6.

System 1 sediments consist of grey to grey brown sandy clay that is interpreted as gully (unit 8) and point bar deposits (unit 7); these have a dominance of EM3, but the point bar deposits have sand layers and a significantly higher finer proportion of EM4. Grey to light grey silty clays (unit 9) are interpreted as medium-deep water flood basin deposits with an equal dominance of EM3 and 4 and a relatively low EM1 + EM2. Organic shallow-water flood basin deposits are indicated by grey to dark grey silty clay with similar endmember properties as unit 9.

System 1 is the basal unit, everywhere located on top of the Holland Peat or, if eroded, directly on top of the Wormer layer (Fig. 5). The top of the gully deposits is most likely eroded by younger systems. The gully deposits of system 1 are located in the centre of Fig. 5 between cores 7 and 53, flanked on the west by flood basin deposits between cores 8 and 14. In the north-south profile, the system 1 gully (channel and point bar deposits) is located from core 53 southward to where it is cut off by system 4 (Fig. 6). To the north the gully deposits are bounded by flood basin deposits in core 2 . In core 58, channel deposits are observed, also bounded by flood basin deposits to the north. At cores 28-55, system 1 flood basin and peat deposits also occur at higher levels, with the top between 0.25 and $1.5 \mathrm{~m}$-NAP, confirmed by AMS carbon-14 and archaeological dating (Fig. 3; van Dasselaar, 2011). In cores 29 and 30, the combined data of archaeological dating and carbon-14 analysis (1130 $\pm 35 \mathrm{BP}$, core 29; Fig. 3) as well as the observation of a Fluvisol profile in unit 10 below the peat in core 29 (Fig. 6a) suggest a stable surface for a considerable amount of time (500-1000 years).

In system 1 TGA data of sediments show patterns of relatively high amounts of "old carbon" in flood basin deposits (units 9 and 10), while carbonate content is increased in the "gully" deposits (units 7 and 8; Table 4). The latter high value of carbonate content in conjunction with the presence of freshwater and continental shell remains points to a provenance of detrital carbonates transported to this region with the Maas river.

System 2, interpreted as gully sediments (unit 8), consists of grey silty clay deposits with sand layering, a dominance in EM3, marine shells, and a relatively high proportion of EM1 + EM2 $(\sim 10 \%)$. Flood basin deposits in this system consist of grey silty clay with continental shell material with dominant EM3 and relatively low EM1 + EM2 proportions. Light brown silty clay with detritus and peat layering is interpreted as shallow-water flood basin deposits.

System 2 is much more confined and is located in the east-west profile only in the centre part, eroded by younger 
systems elsewhere (Fig. 5). Also, in the north-south profile, system 2 is confined to the city centre of Vlaardingen and is eroded on the south side by the Maas river and potentially on the north side by younger incisions of systems 3 and 3.1 (Fig. 6). The top of system 2 is between 0.00 and $0.50 \mathrm{~m}$ - NAP, dated to AD 1000-1170 determined by radiocarbon dating and archaeological remains in that system (Kluiving et al., 2014; van Dasselaar, 2011). The basal parts of system 2 suggest a medieval age (AD 600-1000) of the fluvial sediments, given by the radiocarbon and archaeological dates in cores 29 and 30 (Fig. 6) and core 17 (Fig. 5).

System 3 gully deposits (unit 8) consist of a grey sandy to silty clay with sand banding with a dominance of EM3 and a relatively high proportion of EM1 + EM2 (>10\%). The gully sediments contain continental and freshwater shell remains. (Dark) grey to (light) brown silty clay (10) is interpreted as organic flood basin deposits with double the amount of EM3 vs. EM4. The dark-coloured sediment with the humus-detritus banding and staining is interpreted as shallow-water flood basin deposits that are in this stratigraphic position often disturbed by human influence.

System 3 with associated gully and floodplain sediments has a rather discontinuous presence in the east-west profile (Fig. 5), while the system appears to be dissected by younger systems as well as by non-deposition also in the north-south profile due to relatively high (non-eroded) remnants of systems 1 and 2 (Fig. 6). Two of the system 3 gullies are located within $10-25 \mathrm{~m}$ of the old church. The top of system 3 is between 0 and $0.20 \mathrm{~m}-\mathrm{NAP}$ in north-south profile B-B' and even between 0.20 and $0.50 \mathrm{~m}+\mathrm{NAP}$ in the east-west profile profile A-A'. System 3 is dated AD 1170-1300 by AMS carbon-14 and relative dating (Figs. 3, 5a, 6a).

System 3.1 gully deposits of sandy clay to clayey sand appear in the top of the system and are sparsely sampled. The dark grey to grey brown silty clay with humus staining is interpreted as shallow-water flood basin deposits. The EM4 endmember slightly dominates the EM3 fraction, while the anthropogenic influence is reflected in the high proportion of EM1 + EM2 (>20\%). Dark grey silty clay has a similar EM3-EM4 relation but has a lower proportion of $\mathrm{EM} 1+\mathrm{EM} 2$ of almost $10 \%$. These sediments are interpreted as medium-deep water flood basin deposits. System 3.1 also has a significantly high amount of archaeological remains.

In both profiles, system 3.1 has a more continuous cover, of which the top occurs between 1.20 and $0 \mathrm{~m}+\mathrm{NAP}$ in the city centre, and between 0 and $2.5 \mathrm{~m}-\mathrm{NAP}$ on the west side of the city centre (Fig. 5). System 3.1 is dated AD 11701300 by relative dating (Figs. 5a, 6a). Within system 3.1 at some locations we are able to distinguish two subsystems: system 3.1a and system 3.1b (Fig. 6). While 3.1a can be interpreted as an erosive phase forming gullies, $3.1 \mathrm{~b}$ is by contrast interpreted as (i) a dike body and (ii) as sediments raised by humans to elevate the surface. While the gullies are dated to around $\mathrm{AD} 1170$, the dike body and raised sediments are dated after that date (AD 1170-1300).
System 4 gully deposits (unit 7-1) are grey silty sands and have an EM1 + EM2 of $60 \%$. Grey to light brown silty clay with silt-sand banding is interpreted as point bar deposits has a dominant EM3 and an EM1 + EM2 of almost $20 \%$. Flood basin deposits of system 4 have similar characteristics to other systems.

System 4 only occurs in the southern part and incises systems 1 and 2 as well as potentially system 3 (not observed). System 4 is covered by systems 3.1 and 6; the top of this system is at $1.0 \mathrm{~m}-\mathrm{NAP}$ and is relatively dated as being older than AD 1170 (stratigraphically below system 3.1). System 4 correlates with Maas river deposits and Echteld Formation (Fig. 6).

System 5 gully deposits (unit 8) are grey silty clay, sand and humus banding with a dominant EM3 and with a $<10 \%$ $\mathrm{EM} 1+\mathrm{EM} 2$. Grey sandy clay has EM1 + EM2 of $33 \%$ with a slightly dominant EM3 over EM4, interpreted as point bar deposits. Grey to grey brown silty clay has a dominant EM4 proportion.

System 5 only occurs in the eastern part of the research area (Fig. 5); note also the deep occurrences of these sediments in the northern part of the north-south profile (Fig. 6). System 5 incises deeply even into system 1 sediments and is covered by systems 3 (although barely) and 3.1. The stratigraphic top of system 5 is at $0.50 \mathrm{~m}-\mathrm{NAP}$ while the system is dated to AD 1100-1170, which is confirmed by AMS carbon-14 and archaeological dating.

System 6: the (dark) grey to grey black silty clay with peat banding and humus staining, which resembles similar interpreted shallow-water flood basin deposits in previous systems has a significantly higher proportion of EM1 + EM2 $(\sim 27 \%)$. EM3 and EM4 are similar in this anthropogenically influenced deposit. Grey silty clay resembles deeper flood basin deposits with a dominant EM3 proportion and with EM1 + EM2 being $\sim 19 \%$. Especially the remaining deposits of sand, (humic) sandy clay, clayey sand, and silty sand vary from entirely grey to various colours and have extremely high proportions of EM1 + EM2 of $60-90 \%$ (Tables 3,4$)$. Observations of the carbonate content and comparisons with lower systems show that system 6 has significantly lower carbonate values (Table 4). This may be due to the fact that soil-forming processes were going on when this material was exposed after it was piled up. An alternative option would be that the material from system 6 is transported from elsewhere with a substrate with a lower carbonate value. The very coarse nature of the grain size may support the latter explanation.

System 6 is the topmost layer and covers all lower systems with a $2.5 \mathrm{~m}$ thickness in the city centre in an elongated shape while at the eastern and western margins of that centre the thickness of system 6 is only $1 \mathrm{~m}$ (Fig. 5). The relative age of this system is determined at AD 1300 at the base until the present at the surface, interpreted as an entirely cultural system, caused by human interference. The interpretation of system 6 is directly opposed to the other naturally deposited 
systems 1,2 , and 4 , while systems $3,3.1$, and 5 take an intermediate position and are interpreted as minor to major influenced by human's actions.

\section{Discussion}

The natural subsurface of the city centre of Vlaardingen consists of an inversion relief of a number of river systems with sandy gully deposits in a chronological sequence. These river systems are underlain by the silt-poor calcareous clay of the Wormer layer of the Naaldwijk Formation (80005500 years BP) and the Holland Peat layer of the Nieuwkoop Formation (5500-3000 BP). The oldest (river) system 1 in this study is incised in both of these two formations to a depth of at least $6 \mathrm{~m}-\mathrm{NAP}$ (Fig. 5).

Micromorphological evidence has demonstrated evidence of burning (micro-charcoal remains) as well as slags in flood basin deposits in the top of this system between 300 and $350 \mathrm{~cm}$-NAP, while also a few archaeological traces have been found at a deeper level in gully deposits of this system (van Dasselaar, 2011). In a few places, the top of system 1 reaches elevations of almost $0 \mathrm{~m}$ NAP, indicative of erosive processes later on.

The settling traces that have been found in the flood basin deposits belong to the oldest gully in the subsurface of Vlaardingen. System 1 correlates to the Hoogstad creek system of the Vlaardingen system (De Ridder and van Loon, 2007) and dates at least to the Roman period. Considering the fact that there appears to be a hiatus in deposition after system 1 of approximately 1000 years, soil development, i.e. Fluvisols, may be expected on such a surface. In general these soils are only present on stable surfaces, which indicates that the top of system 1 is in fact such a surface. The observation of indications of a few palaeosol features might confirm this (Figs. 5a, 6a). In addition the XRF results indicate that almost all nine measurements have their lowest chemical element occurrence at the top of system 1 and that elements $\mathrm{P}, \mathrm{Cu}$, and $\mathrm{Pb}$ increase above this level (Table 5).

The north-south profile suggests that the gully erosion of system 5 had at least predecessors in system 2 and possibly also systems 1 and 3 (Fig. 6). This implies that the position of the gully shape west of the Vlaardingen centre was almost continuously filled with water at several stages in the last 3000 years.

System 2 is interpreted as a former river deposit only occurring in the centre of the study area, having been deposited between AD 600 and 1170, just before the late medieval storms started to threaten the city. It is inferred that shortly after the deposition of this system most system 2 sediments around the medieval terp were eroded and swept away during later storms and floods, explaining the now isolated occurrence of these sediments. Between cores 38 and 5 in Fig. 6 the age of interpretation of the upper part of system 2 can be disputed based on the findings of an archaeological ex- cavation that the cemetery in this location has been anthropogenically raised since AD 1000 . However, in this case it is tempting to test the hypothesis that the cemetery was raised by inhabitants as a reaction to the flooding and sedimentation of system 2 starting in AD 1000. A possible point of discussion is the fact that the lower age of AD 600 of system 2 may support the hypothesis that in the 6th or 7th century AD renewed activity of creeks and rivers started to make the area more attractive for habitation. Potentially, a church was then built at the location of Vlaardingen that already existed in the early 8th century (Koch, 1970). Following this, the traces of soil formation observed at the top of system 1 suggest a relatively long stable period of the order of 500 years when no deposition or other sedimentary processes were present and soil-forming processes could dominate.

In system 3 many small-scale gully erosional forms occur, similar to the upper part of system 5 , indicating a reactivation at the end of the sedimentary cycle. This could be caused by high water stands tied to storm events. Also in system 3.1 many small erosional or partly depositional traces (sand, sandy clay) point to stream activity in the late Middle Ages (e.g. during storm events), with the surrounding organic clays interpreted as the accompanying flood basin deposits. In the other cores, two sedimentation cycles have been clearly observed within system 3.1 (Kluiving et al., 2014).

In geological terms, system 3 can be considered a naturally deposited sedimentary system. This is in contrast with the case of a thick sequence in cores 55, 56, 46, 47, and 49, where archaeologists have interpreted the findings as indicating a dike body (system 3.1b), based on the occurrence of reed packages that have been generally observed in dikes in the western Netherlands. It is not unlikely that first flooding and deposition of units 3 and 3.1 took place in the northern part of the study area, after which damming and dike building activities became a necessity observed in system $3.1 \mathrm{~b}$ (Fig. 6).

The interpretation of system 3.1 is also debatable; it may be considered a natural deposit based on the sedimentological characteristics or an anthropogenic cover layer based on the relatively high number of archaeological artefacts preserved within this unit. Based on lithological characteristics, a number of gullies have been observed around the position of the old church, supporting a natural origin of these deposits. A number of distortions at the top of system 3.1 testifies to human influence on this surface. The subdivision within system 3.1 in subsystems $3.1 \mathrm{a}$ (seminatural) and 3.1b (cultural) clearly observed in the north-south profile (Fig. 6) might be a guide in performing more detailed analysis in the near future on these multiple natural and cultural systems that date roughly between AD 1070 and 1300 . In our current interpretation the seminatural system 3.1 a has eroded the substrate down to 2.5 and $4.5 \mathrm{~m}$-NAP compared to the middle and northern parts of the B-B' cross-section (Fig. 6).

Regarding the lithological signature of the human-induced layers, the working hypothesis is that the terp layer lithology 
reflects the content of the immediate natural substrate. There appears to be a hiatus in deposition after the deposition of system-1-associated lithological unit sediments. The hiatus is supported by relative dating methods, traces of observed initial soil formation, and trends in XRF analyses.

A specific feature in this study is the comparisons between scales; while archaeology is usually concerned with smallscale excavations, geology by contrast adheres to the 500$1000 \mathrm{~m}$ long profile reconstructions. It is important to bear in mind that in the dynamic landscape history of late medieval Vlaardingen, elevation differences of systems occur, leaving relatively old surfaces as non-eroded cliffs intact at relatively high elevations, while younger systems may be incised at a lower level and on a metre scale.

The upper two systems below system 6,3 and 3.1, have a stratigraphically high position; the top surface of system 3 reaches 0 and $0.50 \mathrm{~m}+\mathrm{NAP}$, and that of system 3.1 reaches between 0 and $1.20 \mathrm{~m}+\mathrm{NAP}$. In the late Middle Ages (AD 1200-1500), the palaeosurface for the peat area in the Vergulde Hand was assumed to be at approximately $1 \mathrm{~m}+\mathrm{NAP}$, which was before the considerable surface lowering due to human-induced peat drainage. This late medieval surface of the peat area was lowered to approximately $2 \mathrm{~m}-\mathrm{NAP}$ by AD 2000 (Vos and Eijskoot, 2009). This elevation corresponds to the top surface of system 3.1 at the western side of the city centre (Fig. 5).

The fact that we interpret system 3.1 as partly naturally deposited during flooding events is supported by observations on grain size and archaeological dating results. The difficulty with this interpretation is that, after the flooding event, the surface and upper part of system 3.1 were subjected to building activities, such as the construction of houses and dikes. In our current interpretation, the dike in the subsurface of the north-south profile (system 3.1b) was erected after the flooding event associated with the deposition of system 3.1a (Fig. 6). More detailed analysis will be necessary to compare lithology, trends, and archaeological dating on a specific time frame, e.g. AD 1000-1300, to sort out differences between natural and cultural layers.

The discussion of how to distinguish between natural and cultural deposits is a typical interdisciplinary research question. Regionally, so far no comparisons of city histories in a lowland environment have been undertaken with similar research approaches. Future research will have to consider whether the hypothesis that systems 2,3 , and 3.1 are in part naturally deposited systems can be tested positively given new archaeological, historical, and sedimentological research, including soil analyses on Fluvisols in this region.

\section{Conclusions}

An integrated interdisciplinary analysis of the subsoil of Vlaardingen Stadshart has delivered the following key data:
- The medieval city centre of Vlaardingen is situated on top of an old river inversion landscape that provided opportunities for settlement.

- The oldest system 1 in this study correlates with the Hoogstad creek of the Vlaardingen system and is relatively dated to have ended 2000 years BP (De Ridder and van Loon, 2007). This relatively old river course is confirmed by the initial soil development of Fluvisols that has been observed in a few cores. This is supported by the XRF analysis that indicates that the elements $\mathrm{P}$, $\mathrm{Cu}$, and $\mathrm{Pb}$ increase above this system.

- The start of system 2 around 600 AD correlates with archaeological evidence of the church that was present in at least AD 726/727 (Koch, 1970, no. 2), suggesting the start of the Vlaardingen village after a relatively long period of stability.

- The gully shape east of the city centre was active, with water running from north to south, for more than 2000 years BP until AD 1400-1500.

- It has been debated in this paper that the higher systems 2,3 , and 3.1, although in part intensively anthropogenically disturbed, may represent in part natural and anthropogenetic deposits until AD 1300, corresponding to the increased frequency of floods in the late Middle Ages. Future research focussing on the genesis of the surficial systems in this urban context will undoubtedly contribute to this intriguing interdisciplinary research question to further unravel the history of Vlaardingen.

- The upper system 6 is interpreted to have been piled up by human action starting from AD 1300 until the present. Premature soil formation (decalcification) may have affected the system in the previous 600 years. The nature of the lithology of this anthropogenic system suggests provenances other than the Stadshart.

Author contributions. Sjoerd Kluiving coordinated the research and wrote the manuscript. Tim de Ridder held the archaeological supervision on the project and contributed to writing. Marcel van Dasselaar carried out the archaeological research in Vlaardingen and contributed to writing. Stan Roozen constructed the figures. Maarten Prins supplied the GSA and TGA data and contributed to writing.

Acknowledgements. Many thanks go to Richard Exaltus (Micromorphology), Lisette Kootker and Laura van der Sluis (bone analysis), Kay Koster (TGA and XRF analysis), Wim Kuiper (shell remain analysis), and Steven Soetens (mapping, GIS). The paper benefitted very much from the comments made by reviewers Jan van Mourik, Paul Sinclair, and Timothy Beach.

Edited by: J. van Mourik 


\section{References}

Buisman, J. and van Engelen, A. F. V.: Duizend jaar weer, wind en water in de lage landen, deel 1 tot 1300, Van Wijnen, Franeker, 2000.

Courty, M. A., Goldberg, P., and Macphail, R.: Soils and micromorphology in archaeology, Cambridge university press, Cambridge, 1989.

de Ridder, T.: Waar ligt het oude Vlaardingen? Een nieuw model voor een oude stad, Terra Nigra, 155, 36-52, 2002.

de Ridder, T. and Van Loon, C.: Projectcode BC006, Het profiel van Vlaardingen, VLAK-verslag 44, 2007.

de Ridder, T., Altena, E., de Knijff, P., Vredenbregt, A. H. L., and Luth, H. J.: De zoektocht naar de oer-Vlaardinger, Westerheem, special nr. 1, 28-38, 2008.

FAO: World Reference Base for Soil Resources, Version 2007, 2007.

Hijma, M. P., Cohen, K. M., Hoffmann, G., Van der Spek, A. J. F., and Stouthamer, E.: From river valley to estuary: the evolution of the Rhine mouth in the early to middle Holocene (western Netherlands, Rhine-Meuse delta), Neth. J. Geosci., 88, 13-54, 2009.

Hoek, C.: "De Middeleeuwen", in: Van steurvisser tot stedeling, edited by: Vos-Dahmen von Buchholz, T., Flenio, Vlaardingen, 1973, 118-146, 1973.

Jongerius, A. and Heintzberger, G.: Methods in soil micromorphology; a technique for the preparation of large thin sections, Soil survey papers 10, Soil Survey Institute, Wageningen, The Netherlands, 1975.

Kluiving, S. J. and Vorenhout, M.: Interdisciplinair onderzoek naar archeologie, geologie, hydrologie en conservering van het cultureel erfgoed in de ondergrond van het Stadshart van Vlaardingen, een testonderzoek, IGBA rapport 2010-01, Vrije Universiteit Amsterdam, the Netherlands, 2010.
Kluiving, S. J. and Vorenhout, M.: Programma van Eisen, Stadshart te Vlaardingen, Vlaardingen, IGBA Rapport 2011-07, Vrije Universiteit Amsterdam, the Netherlands, 2011.

Kluiving, S. J., Koster, K., and Roozen, S.: Analyse van korrelgrootte, thermogravimetrische en röntgen fluorescentie eigenschappen van sedimenten uit mechanische boorkernen in het Vlaardingen-Stadshart project, IGBA Rapport 2012-05, Vrije Universiteit Amsterdam, the Netherlands, 2012.

Kluiving, S. J., van Dasselaar, M., Exaltus, R., Kootker, L., Koster, K., Kuiper, W., Lange, S., de Ridder, T., Roozen, S., van der Sluis, L., and Soetens, S.: Synthese Vlaardingen Stadshart, IGBA Rapport 2014-01, Vrije Universiteit Amsterdam, the Netherlands, 2014.

Koch, A. C. F.: Oorkondenboek van Holland en Zeeland tot 1299, I: Eind van de 7 e eeuw tot 1222, Nijhoff, 's-Gravenhage, the Netherlands, 1970.

Torremans, R. and de Ridder, T.: Bureauonderzoeken 21, Plangebied Stadshart, Vlaardingen (uitgave VLAK), 2007.

van Dasselaar, M.: Archeologisch onderzoek Stadshart te Vlaardingen, ArcheoMedia rapport A11-009-I, Capelle aan den IJssel, the Netherlands, 2011.

Vos, P. C. and Eijskoot, Y.: Geo- en archeologisch onderzoek bij de opgravingen van de Vergulde Hand West (VHW) in Vlaardingen, Deltares-rapport, 0912-0245, 160 pp., 2009.

Weltje, G. J. and Prins, M. A.: Muddled or mixed? Inferring palaeoclimate from size distributions of deep-sea clastics, Sediment. Geol., 162, 39-62, 2003.

Widgren M.: Landscape research in a world of domesticated landscapes: The role of values, theory, and concepts, Quatern. Int., 251, 117-124, 2012.

WRB: World reference base for soil resources, available at: http: //www.fao.org/3/a-i3794e.pdf, last access: 14 August 2014. 